Розділ І. Ціннісні орієнтири духовно-інтелектуального виховання, розвиток духовно-інтелектуальних якостей особистості в умовах співпраці й інклюзії

\title{
ВПРОВАДЖЕННЯ ДУХОВНИХ ЦІННОСТЕЙ В ОСВІТНІЙ ПРОЦЕС ЗАКЛАДУ ДОШКІЛЬНОЇ ОСВІТИ
}

\author{
Лазаренко Г. А. \\ кандидат педагогічних наук, головний спеціаліст Управління освіти \\ адміністрації Московського району Харківської міської ради, \\ м. Харків, Україна
}

У статті аналізується проблема духовного виховання дитини дошкільного віку, прищеплення ій духовних иінностей, щчо сприятимуть формуванню уявлень добра, справедливості, чесності, гуманізму, патріотизму, моральних норм та правил. Розкрито деякі підходи виховної практики, які дозволяють закладати фундамент духовності у становленні дитини як особистості.

Ключові слова духовне виховання, духовні ичінності, дошкільне виховання, діти дошкільного віку.

The article analyzes the problem of spiritual education of a preschool child, instilling in him spiritual values that will contribute to the formation of ideas of goodness, justice, honesty, humanism, patriotism, moral norms and rules. Some approaches of educational practice are revealed, which allow laying the foundation of spirituality in the formation of a child as a person.

Keyword: spiritual education, spiritual values, preschool education, preschool children.

Однією 3 найгостріших проблем українського суспільства на сучасному етапі його розвитку є падіння рівня моралі, втрата духовних орієнтацій, нездатність людей до самопізнання, відсутність потреби у самовдосконаленні, саморозвитку. Тому принципи духовної педагогіки, які поєднують моральні ідеали та загально-людські цінності, значення душі та духовного виховання є особливо актуальними сьогодні в нашій державі.

Дошкільний період — важливий етап у становленні різних сторін особистості. Велике значення в особистісному зростанні дитини має аспект формування початків духовності в напрямках закладання основ культури міжособистісного спілкування, моральної, громадянської, художньо-естетичної, родинно-побутової, правової, інтелектуальної, екологічної, релігійної (за бажанням родин) культури (В. О. Огнев’юк). 
Щоб здобути бажані результати, важливо постійно інтегрувати означені напрями у життєдіяльність дошкільника, не обмежуючись одним iз них.

Як показують наукові дослідження багатьох відомих педагогівкласиків: Г. Ващенка, І. Огієнка, С. Русової, К. Ушинського, В. Сухомлинського, а також сучасних педагогів: А. Богуш, О. Вишневського, В. Жуковського, М. Євтуха, Л. Москальової, Т. Саннікової, І. Сіданич, Г. Шевченко, дошкільний період - надзвичайно сприятливий для духовного розвитку та закладання базису духовних цінностей, а саме: почуття любові й поваги до рідних і близьких, інших людей, батьківської домівки, дитячого садка, рідного села, міста, інтересу до історичної та культурної спадщини українського народу, гуманного та толерантного ставлення до інших, пізнання самого себе [2].

Аналіз наукової літератури показав, що поняття духовність - це категорія людського буття, якою виражається його здатність до самотворення та творення культури [5]. Духовність $є$ вищим рівнем розвитку особистості, на якому основними мотиваційно-смисловими регуляторами їі життєдіяльності є вищі людські цінності. Цей рівень найбільш зрілої і відповідальної (перед собою та іншими) особистості, здатної не тільки пізнавати та відображати довкілля, а й творити його. Духовні цінності виражають стан духовності суспільства та особистості, є своєрідним індикатором культурності індивідуальності, сутністю людського в людині [1].

Потреба віри, духовного самовдосконалення є вродженою і особливо виразно спостерігається у дітей дошкільного віку [2]. Прищеплення духовних цінностей дітям дошкільного віку можливо проводити різними засобами та в різних напрямах. Дослідники проблем виховання дітей дошкільного віку наголошували на тому, що духовний розвиток особистості буде ефективним за умови включення дітей у:

- спілкування з однолітками та дорослими (А. Богуш, М. Лісіна, Т. Павленчик, Т. Репіна), гру (Л. Артемова, М. Лісіна, Г. Люблінська, Т. Поніманська, Є. Суботський),

- художньо-пізнавальну діяльність (Н. Бібік, Н. Вашуленко, Ю. Пелех, О. Савченко).

Для реалізації першої умови в закладах дошкільної освіти організовано проведення ранкових зустрічей. Дані зустрічі пропонуються Базовим компонентом дошкільної освіти [3]. Ранкові зустрічі прово- 
Розділ І. Ціннісні орієнтири духовно-інтелектуального виховання, розвиток духовно-інтелектуальних якостей особистості в умовах співпраці й інклюзії

дяться у формі структурованої ранкової бесіди на килимку, коли всі діти вже зібрались у групі. Вони містять чотири основні компоненти: привітання, обмін інформацією, спільна діяльність та щоденні новини. Метою таких зустрічей є навчання дітей взаємної поваги та доброго ставлення одне до одного, сприяння формування цілісного колективу, моделювання очікуваної поведінки, а також можливість показати дітям, що вони є колективом, і водночас, частиною більшості. Під час проведення таких бесід головним завданням вихователя є налаштувати дітей на дружнє й довірливе спілкування, яке вчить 3 повагою та любов'ю ставитися до однолітків, створює умови до прояву дружби, доброти, співчуття, розуміння, мотивує до різних проявів активності. Тематика таких зустрічей досить різноманітна, а саме: «Вдячність за життя», «Вияв любові до батьків», «Садочок любимий - єдина родина!», «Щастя мати дім та затишок у нім», «Здоров’я - найбільший скарб людини», «Турбота про друзів. Друг пізнається в біді» тощо. Також присутня тематика виховання любові до Батьківщини на прикладах національної духовної культури: «Моя мала Батьківщина», «Твори для дітей Т.Г. Шевченка, Лесі Українки», «Любов до Батьківщини», «Державні символи».

Залучення дошкільників до художньо-пізнавальної діяльності відбувається на заняттях художньо-естетичного циклу: музичні, образотворчого мистецтва, слухання творів художньої літератури, театралізованої діяльності. А також особливої популярності серед дітей дошкільного віку набули творчі заняття з «пісочної анімації». Завдяки цьому методу діти навчаються будувати з піску і невеликих фігурок свій індивідуальний та неповторний світ у мініатюрі [4]. На початковому етапі педагог передає малечі уявлення про навколишній світ, допомагає пізнати свій внутрішній. Спонукає малюків до відтворення дітьми образів за іiі зразком. На наступному етапі роботи, озброївшись необхідними практичними вміннями та остаточно зацікавившись роботою з піском, вихованці самостійно відтворюють казкові історії. На заключному етапі діти самостійно малюють історії на задану тематику: «Різдвяні історії», «Пори року», «Моя матуся». «Морське царство» тощо. На піску діти відтворюють те, що виникає у свідомості, висловлюють власні емоції, про які не можуть сказати. Заняття пісочною анімацією розвивають сенсорні відчуття, сприятливо впливаючи на емоційний стан та позитивне 
ставлення дитини до оточуючого, що стає індикатором становлення іiі духовних цінностей.

Отже, процес формування духовних цінностей у дітей показав, що саме період дошкільного дитинства $є$ найбільш сприятливим для формування основ духовності, духовних цінностей, будування на цій основі сприйняття світу та світоставлення.

Зазначаємо, що проведене дослідження не вичерпує порушеної проблеми. Предметом подальшого наукового пошуку може бути вивчення питання щодо прищеплення духовних цінностей під час проєктної діяльності.

\section{Список використаних джерел:}

1. Богуш А.М. Духовні цінності в контексті сучасної парадигми виховання. Виховання і культура. 2001. № 1. С. 7.

2. Духовно-моральне виховання дітей дошкільного віку на християнських цінностях: навч. прогр. та календарно-темат. план / А.М. Богуш, І.Л. Сіданіч, В.С. Сучок та ін. Київ : ВБФ «Східноєвропейська гуманітарна місія», 2019. 164 с.

3. Щодо методичних рекомендацій до оновленого Базового компонента дошкільної освіти : Лист Міністерства освіти і науки України від 16.03.2021 № 1/9-148 URL: https://mon.gov.ua/ua/npa/shodo-metodichnihrekomendacij-do-onovlenogo-bazovogo-komponenta-doshkilnoyi-osviti (дата звернення: 08.10.2021 р.).

4. Мусатенко О.В. Пісочна анімація як засіб розвитку творчих здібностей дітей старшого дошкільного віку. Дошкільна освіта в Україні: вчора, сьогодні, завтра : матеріали IV науково-практичної конференції студентів факультету дошкільної освіти (18-19 квітня 2019 р., м. Харків) / за заг. ред. К.А. Юр'євої. Харків : ХНПУ імені Г.С. Сковороди, 2019. С. 50-55.

5. Суслова І.В. Розвиток духовності дітей старшого дошкільного віку шляхом формування духовних цінностей URL: http://appsychology.org.ua/data/ jrn/v12/i15/i/48.pdf (дата звернення: 01.10.2021р.). 